\title{
DIY urbanism as an environmental justice strategy: The Case Study of Time's Up! 1987-2012
}

\author{
Benjamin Shepard ${ }^{1}$
}

Time's Up! is a New York environmental group which promotes nonpolluting transportation and sustainable solutions to urban problems. Over the last twenty-five years, the group has taken a do-it-yourself approach to environmental activism, bridging neighborhood, global justice, and Occupy movements. With roots in the squatter movement in New York, Time's Up! has built its own distinct brand of DIY urbanism to fight for community gardens, support group bike rides, and create sustainable approaches to urban living. While the group makes use of a wide range of approaches to reclaim public space, direct action is its guiding principle. The group links social networks with alternative approaches to community building outside of institutional channels. The following considers Time's Up! as a case study in environmental justice DIY urbanism. [Article copies available for a fee from The Transformative Studies Institute. E-mail address: journal@transformativestudies.org Website: http://www.transformativestudies.org (02014 by The Transformative Studies Institute. All rights reserved.]

KEYWORDS: DIY Politics, Sustainability, Non-polluting Transportation, Direct Action, Bicycling.

\footnotetext{
${ }^{1}$ Benjamin Shepard, Ph.D., LMSW, works as an Assistant Professor of Human Services at City Tech/CUNY. By night, he has battled to keep New York from becoming a giant shopping mall. To this end, he has done organizing work with the AIDS Coalition to Unleash Power (ACT UP), SexPanic!, Reclaim the Streets, Times UP, the Clandestine Rebel Clown Army, Absurd Response, CitiWide Harm Reduction, Housing Works, More Gardens Coalition, Times UP!, and several Occupy Wall Street committees. He is also the author/editor of six books: White Nights and Ascending Shadows: An Oral History of the San Francisco AIDS Epidemic (1997), From ACT UP to the WTO: Urban Protest and Community Building in the Era of Globalization (2002), Queer Political Performance and Protest (Routledge, 2009) The Beach beneath the Streets: Contesting New York's Public Spaces (with Greg Smithsimon, SUNY Press) and Play, Creativity, and Social Movements: If I Can't Dance, Its Not My Revolution (Routledge, 2011). In 2010, he was named to the Playboy Honor Role as one of twenty professors "who are reinventing the classroom." A social worker, he has worked in AIDS services / activism for two decades, joining ACT UP Golden Gate in the early 1990's, opening two congregate facilities for people living with HIV/AIDS, serving as deputy director for a syringe exchange program, all while remaining active in efforts to bridge the gap between direct action and direct services. Today, he remains involved in organizing efforts. Address correspondence to: Benjamin Shepard, City Tech/CUNY; e-mail: benshepard@mindspring.com.
}

1937-0229 @2014 Transformative Studies Institute 